\title{
Working
}

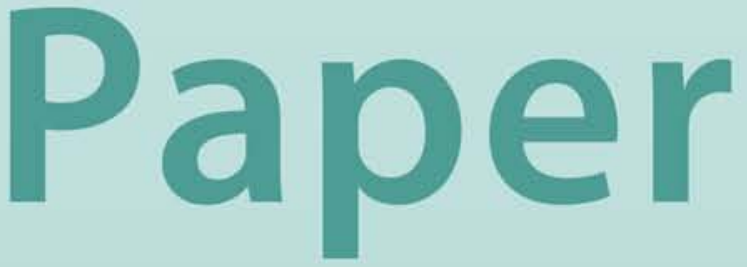


Shaun K. Roache 


\title{
IMF Working Paper
}

Research Department

\section{What Explains the Rise in Food Price Volatility?}

\author{
Prepared by Shaun K. Roache ${ }^{1}$
}

Authorized for distribution by Thomas Helbling

May 2010

\begin{abstract}

\section{This Working Paper should not be reported as representing the views of the IMF.} The views expressed in this Working Paper are those of the author(s) and do not necessarily represent those of the IMF or IMF policy. Working Papers describe research in progress by the author(s) and are published to elicit comments and to further debate.

The macroeconomic effects of large food price swings can be broad and far-reaching, including the balance of payments of importers and exporters, budgets, inflation, and poverty. For market participants and policymakers, managing low frequency volatility-i.e., the component of volatility that persists for longer than one harvest year-may be more challenging as uncertainty regarding its persistence is likely to be higher. This paper measures the low frequency volatility of food commodity spot prices using the splineGARCH approach. It finds that low frequency volatility is positively correlated across different commodities, suggesting an important role for common factors. It also identifies a number of determinants of low frequency volatility, two of which - the variation in U.S. inflation and the U.S. dollar exchange rate - explain a relatively large part of the rise in volatility since the mid-1990s.
\end{abstract}

JEL Classification Numbers: G1, Q00

Keywords: Commodity Markets, Volatility, Agricultural Economics

Author's E-Mail Address: $\underline{\text { sroache@imf.org }}$

\footnotetext{
${ }^{1}$ I would like to thank Jose Gonzalo Rangel, Paul Cashin, Charles Collyns, Nese Erbil, Thomas Helbling, Brad McDonald, Tobias Rasmussen, David Romer, Alasdair Scott, and Kenneth West for comments and suggestions. The usual disclaimer applies.
} 


\section{INTRODUCTION}

Food commodity prices have been on a rollercoaster ride since the mid-1990s. Although attention has focused on the sharp run-up in prices which peaked in mid-2008, followed by the precipitous decline as the global economy entered into recession, prices also declined rapidly during the 1995-2000 period. The macroeconomic effects of large food price swings have been broad and far-reaching, including the balance of payments of importers and exporters, budgets, inflation, and poverty.

It is not only the levels of prices which have had powerful effects, but also their volatilities. As noted by Cashin and McDermott (2002), "although there is a downward trend in real commodity prices between 1862-1999, this is of little practical policy relevance, since it is small and completely dominated by the variability of prices". This volatility has made the policy response to changes in food prices more challenging and complicated the investment and consumption decisions of many businesses and consumers.

It is helpful for a greater understanding of food price volatility patterns to separate volatility into low and high frequency components. Weather and pest related shocks, together with uncertainty about the expected harvest during the growing season, means that food price volatility is subject to pronounced seasonal, or high frequency, effects (Petersen and Tomek, 2005). In contrast, low frequency volatility can be defined loosely as changes in the level of price variability which persist for more than one harvest year. In other words, it is the component of volatility which tends to move slowly through time. For many market participants and policymakers, managing low frequency volatility may be more challenging as uncertainty regarding its persistence is likely to be higher.

The behavior of real food prices since the late $19^{\text {th }}$ century suggests three main stylized facts about volatility (Figure 1). First, it appears to be time-varying over periods of months, years and decades. Over rolling 10-year periods the annualized volatility of real food prices since 1885 has ranged from a low of just under 8 percent (in the mid-1960s) to over 20 percent (during the 1920s).

Second, periods of high and low volatility have persisted for sustained periods. For example, volatility was relatively low during between 1955 and 1970. In contrast, volatility was high for the next 10-15 years through the mid-1980s. This indicates that there is a large component of volatility which moves slowly through time.

Third, there have been four large increases in long-run food price volatility during this sample period. The first two occur during periods when global trade was impeded (the First World War and the inter-war years immediately following and the Second World War), a point made by Jacks, O'Rourke, and Williamson (2009). The next rise in volatility followed 
the breakdown of the Bretton Woods exchange rate regime in the early 1970s, as noted by Cashin and McDermott (2002) and Gilbert (2006). More recently, 10-year volatility reached its highest level in almost 30 years in 2009.

\section{Figure 1. Real Food Price Volatility, 1875-2009}

(annualized standard deviation percent) $1 /$

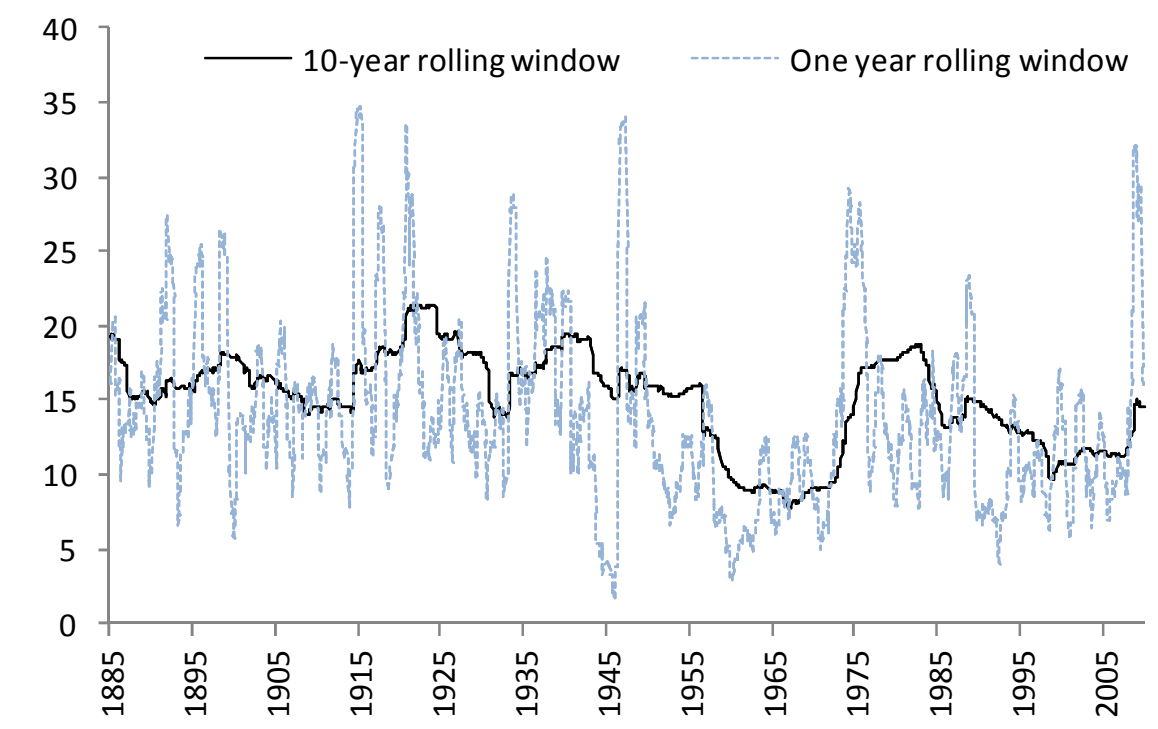

Source: Global Financial Data; IMF; and author's calculations.

1/ Equally-weighted index of 6 commodities, including corn, palm oil, rice, soybeans, and wheat. These U.S. dollar denominated price series are deflated by the U.S. consumer price index.

A greater understanding of how and why low frequency food price volatility is changing would be of value to both commodity market participants and policymakers seeking to address and manage its effects. Until now, there has been very little analysis of the following questions. If the level of price variation changes, how long should those changes be expected to persist? In other words, to what extent is price volatility driven by low and high frequency components, respectively? Are there identifiable causes of changes in low frequency food price volatility? To what extent have these potential causes driven the recent change in volatility?

This paper fills a gap in the literature by addressing these questions directly. The splineGARCH model from Engle and Rangel (2008) is applied to the spot prices of six major food commodities for a sample stretching as far back as 1875: corn, palm oil, rice, soybeans, sugar, and wheat. This model provides an estimate for the low frequency component of timevarying price volatility. The paper also identifies the extent to which macroeconomic and commodity-specific factors have driven long-lasting changes in price volatility over the last 40 years. New results include the findings that low frequency price volatility is positively correlated across food commodities and that a number of factors can affect this measure of food price variation, including real U.S. interest rates, U.S. dollar volatility, and futures market volumes. 
The plan of this paper is as follows. Section II describes the estimation methodology. Section IV provides details on the data. Section V reports the main results, with concluding remarks following in section VI.

\section{Estimation Methodology}

An innovative way to incorporate possible time-variation in low frequency volatility is the spline-GARCH model of Engle and Rangel (2008). The main modification that this approach makes relative to the benchmark GARCH $(1,1)$ model of conditional variance is to incorporate a trend in the volatility process. To identify clearly how the spline-GARCH model is different, this sections begins by describing a standard GARCH $(1,1)$ model. This comprises a mean equation (1a) and a variance equation (1b), where the conditional variance $h$ is a function of moving average and autoregressive terms:

$$
\begin{aligned}
& \Delta p_{t}=\mu+\rho \Delta p_{t-1}+\varepsilon_{t} \quad \text { where } \quad \varepsilon_{t}=v_{t} \sqrt{h_{t}} \quad \text { and } \\
& v_{t} \sim N(0,1) \\
& h_{t+1}=\gamma+\alpha \varepsilon_{t}^{2}+\beta h_{t}
\end{aligned}
$$

In (1a), $\Delta p$ is the change in the log price, $\mu$ is a constant, $\rho$ is the coefficient on the lagged price change to take account of the serial correlation typical of commodity prices, $\varepsilon$ is the innovation in the price change, and $v$ is a white noise disturbance. The conditional variance is denoted by $h$. In (1b), $\alpha$ and $\beta$ are the moving average and autoregressive components of conditional variance, respectively. This implies that the unconditional variance is constant and given by:

$$
E\left(\varepsilon_{t}^{2}\right)=E\left(h_{t}\right)=\gamma(1-\alpha-\beta)^{-1}
$$

The alternative spline-GARCH formulation is expressed in a similar way, with a mean and variance equation. However, there are now two main differences. The first is the presence of a trend $\tau$ in the innovation of the mean equation (3a). The second is the equation which describes this trend process as an exponential quadratic spline (3c):

$$
\begin{aligned}
& \Delta p_{t}=\mu+\rho \Delta p_{t}+\varepsilon_{t} \quad \text { where } \quad \varepsilon_{t}=v_{t} \sqrt{\tau_{t} h_{t}} \quad \text { and } \quad v_{t} \sim N(0,1) \\
& h_{t+1}=(1-\alpha-\beta)+\alpha\left(\frac{\varepsilon_{t}^{2}}{\tau_{t}}\right)+\beta h_{t}
\end{aligned}
$$


$\tau_{t+1}=k \exp \left[w_{0} t+\sum_{i=1}^{P} w_{i}\left(\left(t-t_{-i}\right)_{+}\right)^{2}\right]$

where

$\left(t-t_{i}\right)_{+}=\left\{\begin{array}{ccc}t-t_{i} & \text { if } & \text { if } t>t_{i} \\ 0 & & \text { otherwise }\end{array}\right.$

The trend $\tau$ is a latent variable and is a function of a set of $P$ equally-spaced partitions of the time horizon $T$; i.e., a set $\left\{t_{0}=0, t_{1}, t_{2}, \ldots t_{P}=T\right\}$. The parameters to be estimated in the model include $\left\{\mu, \rho, \alpha, \beta, k, w_{0}, w_{1}, \ldots, w_{P}\right\}$. The weighting coefficients $\left\{w_{i}\right\}$ will determine the amplitude of each cycle, with higher values leading to "sharper" cycles. The number of knots in the spline, $P$, determines the number of cycles. This value is unknown and, following Engel and Rangel, is selected using information criteria.

One useful result from this approach is that the latent trend $\tau$ serves as the time-varying unconditional forecast of variance, as shown in (4). This means that the spline-GARCH model relaxes the assumption of a constant unconditional variance.

$E\left[\varepsilon_{t}^{2}\right]=\tau_{t} E\left(h_{t}\right)=\tau_{t}$

The model is estimated using maximum likelihood techniques and the estimate of the low frequency volatility can then be extracted from $\tau$. One cautionary note is that splines tend to behave poorly at the boundaries of the sample as the estimate is dominated by local effects (Rice and Rosenblatt, 1983). A number of methods have been proposed to deal with these effects, including the imposition of zero slope conditions at the boundary. In this paper, the spot price is extrapolated forward, using the results from a GARCH $(1,1)$ model. The price change in each period is obtained from the mean equation, which includes a disturbance term that is the product of the white noise process $v$ and the estimate of that period's conditional standard deviation. These simulated data serve only to solve the boundary problem and avoid overshooting or undershooting estimates of low frequency volatility.

\section{Cross-sectional analysis of low frequency volatility}

The cross-sectional analysis of low frequency volatilities follows the approach outlined by Engle and Rangel (2008). Long-run periods are equated to annual intervals and all variables are calculated over this horizon from monthly data. As shown in (5), for each commodity the annualized average unconditional standard deviation over the marketing year is calculated from the monthly estimates of $\tau$ from (3b).

$$
\sigma_{t}=100 \times 12^{-1 / 2} \sum_{s=1}^{12} \sqrt{\tau_{s}}
$$


Each regressor is annualized in the same way, with averages taken over the relevant marketing year. A number of regressors are in the form of volatilities and these are calculated as the annualized standard deviations of the monthly log changes.

Ideally, this analysis should provide insights regarding those factors that have similar impacts across a range of food commodities; in other words, are there some key variables that influence food price volatility more broadly, rather than just specific crops? The first step in answering this question is to estimate fixed-effects regressions with the stacked commodities as the dependent variable and one single factor as the explanatory variable. This will provide the first indication of possibly significant relationships. This specification for each commodity can be written as:

$\sigma_{i t}=a_{i}+b_{i} z_{i t}+\omega_{i t}$

where $\sigma_{i t}$ and $\mathrm{z}_{i t}$ are the low-frequency volatility estimate and explanatory variable for commodity $i$ at period $t$, respectively. The parameters $\mathrm{a}_{i}$ and $\mathrm{b}_{i}$ are to be estimated. The estimation was then based on a (NT x 1) vector of stacked volatility estimates $\boldsymbol{\sigma}$ and a (NT x 1) vector of stacked explanatory variables, where $N$ is the number of commodities and $T$ is the sample size, Some caution is required when applying fixed-effects regressions to this particular set of data given that the parameters are estimated on the basis of within-groups variation. All of the volatilities and some of the explanatory variables exhibit low variation over time and this can lead to imprecise estimates.

The next step is to estimate a system of multivariate regressions. This system is also estimated jointly for all commodities but now includes all of the explanatory variables identified as possible determinants of low frequency volatility. Initially, all of the slope coefficients vary across commodities. This system can be written in matrix form as:

$\boldsymbol{\sigma}=\mathbf{A}+\mathbf{B Z}+\boldsymbol{\omega}$

Where $\boldsymbol{\sigma}$ is an (NT x 1$)$ vector of low frequency volatility estimates for the $N$ commodities for each of the $T$ years in the sample, $\mathbf{A}$ is a an (NT x 1) vector of estimated constants which vary across commodities but not over time, $\mathbf{B}$ is a an $(N T \times K T)$ matrix of parameters describing the sensitivity of volatility to the explanatory variables which also vary across commodities but not over time, $\mathbf{Z}$ is a $(K T \times 1)$ vector of explanatory variables which may differ across commodities, and $\boldsymbol{\omega}$ is an (NT x 1) of residuals. For each commodity, (7) implies that low frequency volatility for each commodity $i$ can be expressed as:

$\sigma_{i t}=a_{i}+\sum_{k=1}^{K} b_{i k} z_{i k t}+\omega_{i t}$ 
These system regressions were estimated using Generalized Method of Moments (GMM) with Newey-West standard errors to account for clear evidence of both cross-section heteroscedasticity and serial correlation in the residuals. Two of the explanatory variables exhibited potential endogeneity, based on Durbin-Wu-Hausman bivariate regression tests (details available from author on request): oil price volatility and open interest. For these two explanatory variables, one period lags were used as instruments.

To identify sensitivities common to all commodities and to increase the parsimony and degree of freedom of the model, restrictions were applied to the system (7). First, the coefficients on the explanatory variables were restricted to be the same across commodities with the exception of inflation measures (since it was possible to reject the null hypothesis that the inflation coefficients were identical at the 5 percent level). These restrictions can be written as:

$b_{1 k}=b_{2 k}=\cdots=b_{N k} \quad$ for $\quad k=1,2, \cdots, K$

The coefficients on the volatility of oil prices, equity prices, and open interest were set to zero. Both sets of restrictions were accepted by log-likelihood ratio tests and the sequencing or joint imposition of these restrictions made no difference to the results of the tests.

\section{DATA}

\section{Commodity prices}

For commodity spot prices, the full sample runs from January 1875 through December 2009. For the period before 1957, all data are sourced from Global Financial Data and is based largely on cash prices in the major U.S. markets for that crop. The quality of these price series is compromised at certain times due to lack of data; for example, for corn, no data were available between 1943-46 and prices were interpolated during this period. However, such gaps in the data are limited and, for the most part, the prices are representative of those paid at the most important U.S. marketplace for each specific crop.

For the period from January 1957, the actual spot market prices that are published in the International Monetary Fund's International Financial Statistics (IFS) are used. Six commodities are included: corn (maize), palm oil, rice, soybeans, sugar, and wheat. Each of these prices is quoted in U.S. dollars and they are deflated using the U.S. consumer price index. Summary statistics for the log changes of deflated prices of these six commodities, which account for just over one-third of the IMF food commodity index based on export values, are presented in Table 1. The definition and source of each commodity price is provided in Appendix Table A1. For the annual averages of all variables in the crosssectional analysis, the international marketing years as published by the United States 
Department of Agriculture Foreign Agricultural Service Production, Supply, and Distribution (USDA PSD) database are used.

Table 1. Food Commodity Prices 1875-2009 (monthly log change in deflated U.S. dollars multiplied by 100, approximate percent)

\begin{tabular}{lrrrrr}
\multicolumn{7}{c}{ Full sample 1/ } \\
\hline Mean & \multicolumn{7}{c}{ Std. deviation } & Skew & Maximum & Minimum \\
\hline Corn & -0.1 & 7.9 & -0.36 & 52.0 & -61.1 \\
Palm Oil & -0.2 & 7.5 & 0.08 & 32.2 & -30.6 \\
Rice & -0.1 & 7.3 & 0.14 & 66.6 & -74.3 \\
Soybeans & -0.1 & 7.1 & -0.25 & 39.4 & -44.9 \\
Sugar & -0.2 & 8.0 & 0.51 & 52.7 & -34.5 \\
Wheat & -0.1 & 7.3 & -0.08 & 52.6 & -55.4 \\
& Mean & \multicolumn{7}{c}{ IMF index sample 2/ } & \\
\hline \multicolumn{7}{c}{ Std. deviation } & Skew & Maximum & Minimum \\
\hline Corn & -0.2 & 5.2 & -0.18 & 28.2 & -25.5 \\
Palm Oil & -0.2 & 7.5 & 0.08 & 32.2 & -30.6 \\
Rice & -0.1 & 5.9 & 0.94 & 40.6 & -28.5 \\
Soybeans & -0.1 & 6.1 & 0.10 & 31.3 & -35.5 \\
Sugar & -0.1 & 10.4 & 0.25 & 38.5 & -32.4 \\
Wheat & -0.2 & 5.4 & 1.22 & 50.1 & -22.7 \\
\hline
\end{tabular}

Source: Global Financial Data, International Monetary Fund.

1/ These series are spliced together from Global Financial Data sourced data and the IMF Commodity Price Index. All data end December 2009. Start dates vary by commodity; specifically Corn, Sugar, and Wheat begin at January 1975, Palm Oil at January 1957, Rice at October 1914, Soybeans at November 1913.

2/ These series are from the IMF Commodity Price Index. All data start at January 1957 and end at December 2009.

\section{Potential determinants of low frequency food price variation}

Over the long-run, the sources of food price volatility are related mostly to supply-demand fundamentals, which are likely to include market-specific and broader macroeconomic factors. Changes in the underlying volatility of these long-run factors may have large effects on food commodity prices given their typically low short-term supply and demand elasticities (e.g., Askari and Cummings, 1977, and Bond, 1987). Demand also tends to be inelastic, given that many food products are staple items for which consumption is relatively insensitive to changes in prices or income (Seal, Regmi, and Bernstein, 2003), while for higher value food items, the cost of the raw agricultural commodity may not be a significant proportion of the final value of the finished product. The choice of possible determinants of low frequency food price volatility in this paper is informed by theory and the results of other empirical studies.

\section{Inventories}

The seminal theoretical models of commodity pricing posit an important role for inventories, with price volatility increasing as inventories decline (e.g., Williams and Wright, 1991). Empirical evidence, so far, has been mixed on the effects of inventories (e.g., Streeter and Tomek, 1992). To account for this potential effect, an inventory-to-consumption ratio is included for each commodity. Specifically, stocks at the beginning of the marketing year as a 
proportion of the consumption for the previous year at an aggregate world level are used. This ensures that the data are known by the market for that year. (At the very start of the marketing year, both stocks and consumption for the previous 12-months will likely be estimated and those estimates may be refined over time. Typically, the size of these revisions is small.) The source of the data is the USDA PSD database, using standard international trade years.

\section{Macroeconomic factors}

Macroeconomic factors could potentially affect food price volatility through a number of channels and cause persistent changes in the variability of supply and demand over long time horizons. However, disentangling the effects of these factors in terms of their separate effects on both supply and demand is challenging and runs into identification problems. A number of methods have been used to address identification in the context of structural models - see Tomek (1998) — and this is not an issue that will be tackled in this paper. Instead, macroeconomic factors that previous literature has suggested affect commodity price volatility, through either supply or demand effects, are included as regressors.

\section{Inflation}

Inflation is an obvious candidate regressor. Commodities are often regarded as stores of wealth and the incentive to hold them - as financial assets or inventory - increases with inflation. The conventional wisdom that commodities can hedge investment portfolios against inflation risk has also been largely validated by the empirical literature, as noted by Attié and Roache (2009). As a result, inflation levels and variability might affect commodity prices through the portfolio choices of financial investors. The causality can run in both directions, with higher commodity prices leading to higher inflation. Damping these effects, however, are factors such as: the often small proportion of a total food product's price that is accounted for by the raw commodity (Leibtag, 2008); the relatively small weight of individual food crops in the consumer price index basket; and the strong role of uncorrelated commodity-specific shocks to prices.

\section{Exchange rates and interest rates}

Exchange rates can affect commodity prices through a number of channels, including international purchasing power and the effect on margins for producers with non-U.S. dollar costs - see for example Mussa (1986), IMF (2008), and Gilbert (1989). U.S. dollar volatility is included as an explanatory variable and is calculated from the nominal effective exchange rate published by the IMF.

The level of real interest rates can affect commodity prices through a number of supply and demand channels, as noted by Frankel (2006). Whether changes in real interest rate levels or variability have persistent effects on commodity price volatility is less clear and will likely depend on the extent to which market participants expect real interest rate shocks to persist. The level and variability of the U.S. Treasury 3-month bill, deflated by the consumer price 
index, are included as explanatory variables. The difference between the yield on the 10-year U.S. Treasury note and the Treasury bill as a measure of the yield curve is also included, as it could provide information on the expected future path of short-term interest rates.

\section{Global economic activity}

To provide a proxy for global economic activity and demand for commodities, an index of real shipping costs constructed by Kilian (2009) in place of alternatives such as industrial production, as it offers a number of advantages; it does not require exchange-rate weighting and aggregates activity in all countries, incorporating changes in the composition of real output, and changes in the propensity to import industrial commodities for a given unit of real output. At the time of writing, Kilian's index was updated only to February, 2009. To extend the data through December, 2009, the deflated and detrended Baltic Dry Freight index was used.

\section{Oil price volatility}

New potential sources of volatility include factors that drive the demand for biofuels, among them oil price volatility and the effect of ethanol mandates (e.g., Thompson, Meyer, and Westhoff, 2009). To take account of this potential effect, crude oil price volatility is also included, as measured using the U.S. CPI-deflated average petroleum spot price (APSP) calculated by the IMF. Given that biofuels have only recently emerged as a factor for food prices, this regressor may be identifying the direct effects of oil on production costs rather than shifting demand for energy feedstocks.

\section{Global weather patterns}

Measures of global weather patterns caused by shifts in Pacific ocean atmospheric pressure and the resultant El Niño effect are also considered, as some studies have shown this to have a significant influence on commodity prices (Brunner, 2002). This is measured by the Southern Oscillation Index (SOI) and El Niño region 3.4 sea surface temperature (SST) anomalies measured by the U.S. National Oceanic and Atmospheric Administration. ${ }^{2}$ Prolonged periods of negative SOI values coincide with abnormally warm ocean waters across the eastern tropical Pacific typical of El Niño episodes. Prolonged periods of positive SOI values coincide with abnormally cold ocean waters across the eastern tropical Pacific typical of La Niña episodes.

\section{Financial investment and speculation}

The impact of speculators on price volatility has long been the subject of debate (IMF, 2008). Informed speculation can provide liquidity, facilitate price discovery, and improve resource allocation, thereby stabilizing prices. However, if market participants are "irrational," and trade based on emotion and herd mentality, price volatility can increase. The evidence for

\footnotetext{
${ }^{2}$ Data taken from http://www.ncdc.noaa.gov/oa/climate/research/teleconnect/discussion.html.
} 
either hypothesis, until now, has been far from conclusive. Inverse relationships between speculative activity and agricultural commodity price variability has been found by Peck (1981), Brorsen (1989), and Streeter and Tomek (1992). Bessembinder and Seguin (1993), among others, find a positive relationship between futures market volumes and agricultural commodity price volatility. In contrast, Irwin and Holt (2004) conclude that the volume traded and open interest positions of fund managers have no strong and consistent effects on futures price volatility across agricultural commodities.

More recently, UNCTAD (2009) argued that evidence of the role of uninformed trading is the correlation between the unwinding of speculation in different markets that should be uncorrelated. The IMF (2008) shows that during the 2003-08 period there was a positive but weak relationship between return volatilities and the extent of financialization. Two new papers-Robles, Torero, and von Braun (2009) and Amanor-Boadu and Zereyesus (2009) find little evidence that speculative activities might have influenced agricultural commodity prices during the 2005-08 period. Gilbert (2008) shows that the positions of index investors and other non-commercial investors seem to affect future returns for soybeans, but not corn, soybean oil, and wheat.

To capture the effects of financial investment and speculation, the level of both open interest and volume traded for all the futures contracts (at all maturities) traded on the underlying commodity are included. In both cases, the annual average of daily observations is calculated using contracts regarded as benchmarks in each case. These include the Chicago Board of Trade (corn, rough rice, and soybeans); Bursa Malaysia (palm oil); the Intercontinental Exchange (sugar no. 11); and the Kansas Board of Trade (wheat).

\section{Agricultural policies}

The one obvious omission in the multivariate analysis that follows is the effects of agricultural policies, including price supports, direct subsidies, and trade barriers. So far, the literature has not reached a consensus on the effects of policy on volatility. Crain and Lee (1996) find that changes in the volatility of wheat spot and futures markets are highly associated with changing government programs, with more market-oriented programs leading to lower volatility. In contrast, Weaver and Natcher (2000) argue that spot price volatility for corn, soybeans, and wheat increased as government programs became more market-oriented. Similar results were obtained by Yang, Haigh, and Leatham (2001) who focused on the 1996 U.S. FAIR Act, which aimed at increasing the flexibility of planting decisions and reducing government support for crop production. Swaray (2007) examined the demise of international commodity agreements and found few consistent results for food price volatility. Other government interventions may also play a role in volatility, including the loan rate ratio which effectively places a floor under the cash price of crops (e.g., Kenyon et al, 1987). 
The decision to exclude policy variables is primarily driven by the difficulties in obtaining long-run, internationally aggregated data on government programs. Even in particular countries, researchers have often resorted to comparing price variances across different periods characterized by varying policy regimes rather than identifying more precise estimates of sensitivity (e.g,. Crain and Lee, 1996). The OECD provide estimates of total member country support to agriculture starting from 1986, but this would provide a much shorter sample period for the analysis. As a result, single commodity and fixed-effect panel bivariate regressions over the the 1986-2007 sample period are estimated using two measures of policy support separately as explanatory variables: the Producer Nominal Protection Coefficient (NPC), which is the ratio between the average price received by producers at the farm gate and the border price; and the Single Commodity Transfer (SCT) percentage, which is the share of commodity transfers as a share of gross receipts for the specific commodity.

\section{RESUlTS}

The analysis proceeds in two parts. The first part concerns the estimation of low frequency spot price volatility, including how it compares to total volatility and how it has behaved through time. The second part assesses the extent to which low frequency volatility is affected by other variables.

\section{Long-run Volatility Trends}

To obtain estimates of low frequency volatility, the spline-GARCH model described by (3a), (3b), and (3c) was estimated for two sample periods for each commodity: the full sample period starting as far back as 1875 including all available observations for each commodity; and the sample from 1957 onwards, which includes only those prices published by the IMF. The full sample makes use of all available data and provides a very long-run perspective on volatility. However, sample length comes at a cost of accuracy in some cases as highlighted earlier.

To identify the number of knot points $P$ in equation (3c) two specifications were estimated for each sample period: one with 5 year partitions, for which $P=T /(12 \times 5)$; and the other with 10-year partitions, for which $P=T /(12 \times 10)$, where $T$ is the sample length in months. Information criteria were used to select the specification presented in the results. The only change from the specification described above is the addition of the one period lag of the spot

price change in the mean equation ( $3 a$ ) to control for the serial correlation in spot commodity prices that is predicted by theory and is a well-known empirical fact.

The results from models estimated over the 1957-2009 and 1875-2009 periods are shown in Table 2 and Table 3 respectively (the large number of estimated coefficients on the knot points, denoted by $w$ in (3c), have been suppressed in Table 3). Estimates from the GARCH(1,1) described by (1a) and (1b) are also shown. In most cases, the ARCH effects denoted by the coefficient $\alpha$ in (1b), (3b), and the tables are similar in the $\operatorname{GARCH}(1,1)$ and 
spline-GARCH models at about 0.10, irrespective of the number of knot points (although there is more variation for the models estimated over the longer sample period). In contrast the GARCH effects denoted by $\beta$ vary much more, with spline-GARCH models exhibiting significantly less volatility persistence. As Engel and Rangel point out, this is a feature shared by other GARCH models that relax the restriction of a constant unconditional variance.

The spline-GARCH model provides a better fit to the data; this is shown by the comparison of information criteria in Tables 2 and 3, with both the AIC and BIC favoring the spline model for all commodities and all sample periods. Finally, the choice for the optimal number of knot points based on information criteria (i.e., the comparison between spline model 1 and model 2 in Table 2 and Table 3) differs across commodities, but is almost identical for each commodity using both sample periods. Low frequency volatility is also very similar for the 1957-2009 period using the models estimated over the long and short sample periods (Figure 1).

Figure 2 shows how estimated low frequency volatility - the variable $\tau$ from equation (3)evolves over time and how it compares to the total conditional volatility estimate $h$ obtained from the $\operatorname{GARCH}(1,1)$ specification in (1). Unsurprisingly, low frequency volatility exhibits less amplitude and follows a smooth curve (a direct result of the spline framework). Common patterns across food commodities do emerge and correlations are mostly positive (Table 4). The average correlation between low frequency food price volatilities is 0.1 for the full sample and 0.3 for the shorter sample. Excluding sugar and rice, these correlations rise to 0.5 and 0.6 , respectively. The stylized facts about volatility identified above also apply to low frequency variation. Specifically, there has been significant time variation and almost all food commodities experience increases in low frequency price variation during the inter-war years, the Second World War, the mid-1970s, and the last 5-10 years.

In particular, low frequency volatility: increases during the interwar years 1918-39, which confirms the results of Jacks, O'Rourke, and Williamson (2009). It falls and remains very low, relative to its own history, through the 1950-70 period during the early stages of largescale government agricultural programs. Volatility then rises through the 1970s, following the breakdown of Bretton Woods, a similar result to those of Cashin and McDermott (2002). Finally, after declining from the highs of the 1970s, volatility began to increase again and remains on an upward trajectory. 
Table 2. Estimations of the Spline-GARCH and GARCH(1,1) Models: 1957-2009 1/

\begin{tabular}{|c|c|c|c|c|c|c|}
\hline & Corn & Palm oil & Rice & Soybeans & Sugar & Wheat \\
\hline & \multicolumn{6}{|c|}{$\operatorname{GARCH}(1,1)$} \\
\hline$\mu$ & -0.001 & -0.002 & -0.001 & -0.002 & 0.000 & -0.002 \\
\hline$\rho$ & $0.321^{* * *}$ & $0.332 * * *$ & $0.326^{* * *}$ & $0.309 * * *$ & $0.298^{* * *}$ & $0.359 * * *$ \\
\hline$\alpha$ & $0.020 * * *$ & $0.084^{* * *}$ & $0.150 * * *$ & $0.160 * * *$ & $0.122 * * *$ & $0.092^{* * *}$ \\
\hline$\beta$ & $0.975^{* * *}$ & $0.906^{* * *}$ & $0.746^{* * *}$ & 0.762 *** & $0.822 * * *$ & $0.880^{* * *}$ \\
\hline Log-likelihood & 1045.5 & 843.2 & 1012.7 & 878.3 & 620.2 & 1062.4 \\
\hline Aikaike & -3.156 & -2.543 & -3.057 & -2.924 & -1.867 & -3.207 \\
\hline \multirow[t]{2}{*}{$\mathrm{BIC}$} & -3.129 & -2.516 & -3.029 & -2.895 & -1.840 & -3.180 \\
\hline & \multicolumn{6}{|c|}{ Spline GARCH model 1 (10-year partitions) } \\
\hline$\mu$ & -0.001 & -0.002 & -0.001 & -0.002 & -0.001 & -0.002 \\
\hline$\rho$ & $0.320 * * *$ & $0.331^{* * *}$ & $0.328^{* * *}$ & $0.303^{* * *}$ & $0.292 * * *$ & $0.362 * * *$ \\
\hline$\alpha$ & -0.022 & $0.077^{* *}$ & $0.154 * * *$ & $0.150 * * *$ & $0.120^{* * *}$ & $0.095 * * *$ \\
\hline$\beta$ & $0.892^{* * *}$ & $0.712^{* * *}$ & $0.578^{* \star *}$ & $0.443^{* * *}$ & $0.711^{* * *}$ & $0.849 * * *$ \\
\hline k & $-8.550^{* * *}$ & $-10.862 * * *$ & $-7.557^{* * *}$ & $24.636^{* * *}$ & $-10.529 * * *$ & $-11.988 * * *$ \\
\hline$w(1)$ & $2.74 \mathrm{E}-02 * * *$ & $6.89 \mathrm{E}-02 * * *$ & $2.54 \mathrm{E}-02$ *** & $-4.71 \mathrm{E}-01^{* \star *}$ & $1.37 \mathrm{E}-01^{* * *}$ & $1.52 \mathrm{E}-01 * * *$ \\
\hline$w(2)$ & $-1.50 \mathrm{E}-04^{* * *}$ & $-2.74 \mathrm{E}-04^{* * *}$ & $-8.99 \mathrm{E}-05^{* * *}$ & $1.73 \mathrm{E}-03^{* * *}$ & $-7.55 \mathrm{E}-04^{* * *}$ & $-1.03 \mathrm{E}-03^{* * *}$ \\
\hline$w(3)$ & $4.09 \mathrm{E}-04^{* * *}$ & $4.06 \mathrm{E}-04^{* * *}$ & $1.42 \mathrm{E}-04$ *** & $-2.37 \mathrm{E}-03^{* * *}$ & $8.15 \mathrm{E}-04^{* * *}$ & $1.72 \mathrm{E}-03^{* * *}$ \\
\hline w(4) & $-4.90 \mathrm{E}-04 * * *$ & $-5.31 \mathrm{E}-04^{* * *}$ & $-3.66 \mathrm{E}-04 * * *$ & $5.62 \mathrm{E}-04 * * *$ & $4.59 \mathrm{E}-05$ & $-8.51 \mathrm{E}-04^{* * *}$ \\
\hline$w(5)$ & $9.09 \mathrm{E}-05^{* * *}$ & $4.89 \mathrm{E}-04 *$ & $4.00 \mathrm{E}-04^{* * *}$ & $1.52 \mathrm{E}-04$ ** & $-1.97 \mathrm{E}-04 *$ & $-2.55 \mathrm{E}-04$ \\
\hline$w(6)$ & $4.25 \mathrm{E}-04^{* * *}$ & 2.02E-04 & 2.49E-04 & 7.68E-06 & 6.33E-05 & $8.43 \mathrm{E}-04^{* * *}$ \\
\hline$w(7)$ & $-6.96 \mathrm{E}-04^{* * *}$ & $-9.20 \mathrm{E}-04 * * *$ & $-6.20 \mathrm{E}-04$ ** & $-7.10 \mathrm{E}-05$ & $-6.71 \mathrm{E}-05$ & $-6.68 \mathrm{E}-04$ ** \\
\hline$w(8)$ & $9.39 \mathrm{E}-04^{* * *}$ & $1.25 \mathrm{E}-03^{* * *}$ & $4.86 \mathrm{E}-04$ * & $-4.26 \mathrm{E}-05$ & 1.11E-04 & $5.35 \mathrm{E}-04$ * \\
\hline$w(9)$ & $-1.05 \mathrm{E}-03^{* * *}$ & $-9.23 \mathrm{E}-04 * *$ & $-7.01 \mathrm{E}-04 * *$ & $1.40 \mathrm{E}-04$ & 2.83E-04 & $-6.77 \mathrm{E}-04 * *$ \\
\hline$w(10)$ & $1.04 \mathrm{E}-03^{* * *}$ & 3.91E-04 & $1.06 \mathrm{E}-03^{* * *}$ & $-2.48 \mathrm{E}-04$ & $-5.71 \mathrm{E}-04 *$ & $7.33 \mathrm{E}-04$ ** \\
\hline $\mathrm{w}(11)$ & $-7.73 \mathrm{E}-04 * * *$ & $-6.99 \mathrm{E}-06$ & $-6.93 \mathrm{E}-04 * * *$ & $0.00 \mathrm{E}+00 * * *$ & 3.83E-04 & $-4.86 \mathrm{E}-04 *$ \\
\hline Log-likelihood & 1683.3 & 1471.8 & 1639.5 & 1445.5 & 1240.3 & 1691.8 \\
\hline Aikaike & -5.052 & -4.412 & -4.920 & -4.784 & -3.710 & -5.078 \\
\hline \multirow[t]{2}{*}{ BIC } & -4.943 & -4.303 & -4.811 & -4.674 & -3.601 & -4.969 \\
\hline & \multicolumn{6}{|c|}{ Spline GARCH model 2 (5-year partitions) } \\
\hline$\mu$ & -0.001 & -0.003 & -0.001 & -0.002 & -0.001 & -0.002 \\
\hline$\rho$ & $0.320^{* * *}$ & $0.331 * * *$ & $0.325 * * *$ & $0.301 * * *$ & $0.289 * * *$ & $0.352 * * *$ \\
\hline$\alpha$ & -0.004 & $0.098^{* * *}$ & $0.164^{* * *}$ & $0.166^{* * *}$ & $0.113^{* * *}$ & $0.090 * * *$ \\
\hline$\beta$ & 0.622 & $0.819^{* * *}$ & $0.649 * * *$ & $0.546^{* * *}$ & $0.739 * * *$ & $0.844^{* * *}$ \\
\hline k & $-7.407^{* * *}$ & $-9.841 * * *$ & $-7.925^{* * *}$ & $16.669 * *$ & $-7.475^{* * *}$ & $-3.999 * * *$ \\
\hline$w(1)$ & $-9.67 \mathrm{E}-03^{* * *}$ & $4.87 \mathrm{E}-02$ *** & $3.44 \mathrm{E}-02$ ** & $-3.46 \mathrm{E}-01 * * *$ & $4.91 \mathrm{E}-02$ ** & $-7.14 \mathrm{E}-02^{* * *}$ \\
\hline$w(2)$ & $9.76 \mathrm{E}-05^{* * *}$ & $-1.29 \mathrm{E}-04$ *** & $-1.14 \mathrm{E}-04 *$ & $1.25 \mathrm{E}-03^{* * *}$ & $-1.79 \mathrm{E}-04^{* *}$ & $3.56 \mathrm{E}-04^{* * *}$ \\
\hline$w(3)$ & $-2.09 \mathrm{E}-04^{* * *}$ & $9.13 \mathrm{E}-05$ & 7.49E-05 & $-1.54 \mathrm{E}-03 * * *$ & $2.40 \mathrm{E}-04 * *$ & $-6.44 \mathrm{E}-04 * * *$ \\
\hline$w(4)$ & $1.28 \mathrm{E}-04^{* * *}$ & 2.41E-05 & $1.56 \mathrm{E}-04 * \star *$ & $4.04 \mathrm{E}-04 * * *$ & $-1.63 \mathrm{E}-04$ ** & $4.82 \mathrm{E}-04^{* * *}$ \\
\hline$w(5)$ & $1.03 \mathrm{E}-05$ & 3.84E-05 & $-2.65 \mathrm{E}-04$ *** & $-1.14 \mathrm{E}-04^{* *}$ & $2.02 \mathrm{E}-04^{* * *}$ & $-2.85 \mathrm{E}-04^{* * *}$ \\
\hline$w(6)$ & $-2.59 \mathrm{E}-05$ & 1.77E-05 & $2.83 \mathrm{E}-04$ *** & $-2.27 \mathrm{E}-05$ & $-1.10 \mathrm{E}-04$ ** & $1.30 \mathrm{E}-04$ * \\
\hline Log-likelihood & 1667.6 & 1463.6 & 1631.3 & 1443.1 & 1238.3 & 1691.3 \\
\hline Aikaike & -5.020 & -4.402 & -4.910 & -4.790 & -3.719 & -5.092 \\
\hline $\mathrm{BIC}$ & -4.945 & -4.327 & -4.835 & -4.709 & -3.644 & -5.017 \\
\hline
\end{tabular}

Source: Author's calculations.

1 / Significance of the coefficients at the 1,5 , and 10 percent levels is denoted by **, ${ }^{* *}$, and * respectively. 
Table 3. Estimations of the Spline-GARCH and GARCH(1,1) Models 1875-2009 1/

\begin{tabular}{|c|c|c|c|c|c|}
\hline & Corn & Rice & Soybeans & Sugar & Wheat \\
\hline & \multicolumn{5}{|c|}{ GARCH $(1,1)$} \\
\hline$\mu$ & -0.002 & -0.001 & -0.002 & 0.000 & $-0.003 * * *$ \\
\hline$\rho$ & $0.083^{* * *}$ & $0.190 * * *$ & $0.247^{* * *}$ & $0.204^{* * *}$ & 0.059 ** \\
\hline$\alpha$ & $0.068 * * *$ & $0.068^{* * *}$ & $0.190 * * *$ & $0.075 * * *$ & $0.061 * * *$ \\
\hline$\beta$ & $0.916 * * *$ & $0.845^{* * *}$ & $0.666 * * *$ & $0.902 * * *$ & $0.926 * * *$ \\
\hline Log-likelihood & 2051.1 & 1547.5 & 1645.4 & 2131.4 & 2157.5 \\
\hline Aikaike & -2.440 & -2.570 & -2.709 & -2.536 & -2.567 \\
\hline \multirow[t]{2}{*}{$\mathrm{BIC}$} & -2.427 & -2.553 & -2.692 & -2.523 & -2.554 \\
\hline & \multicolumn{5}{|c|}{ Spline GARCH model 1} \\
\hline$\mu$ & -0.002 & -0.001 & -0.002 & -0.002 & -0.002 \\
\hline$\rho$ & $0.113^{* * *}$ & $0.229 * * *$ & $0.251 * * *$ & $0.203^{* * *}$ & $0.073^{* * *}$ \\
\hline$\alpha$ & $0.165^{* * *}$ & -0.001 & -0.002 & $0.071^{* * *}$ & $0.032 * * *$ \\
\hline$\beta$ & $-0.129 *$ & $0.229 * * *$ & $0.251 * * *$ & $0.889 * * *$ & $0.784 * * *$ \\
\hline Log-likelihood & 3733.0 & 2800.4 & 2796.8 & 3717.9 & 3784.1 \\
\hline Aikaike & -4.410 & -4.626 & -4.620 & -4.392 & -4.471 \\
\hline \multirow[t]{2}{*}{$\mathrm{BIC}$} & -4.303 & -4.520 & -4.514 & -4.285 & -4.364 \\
\hline & \multicolumn{5}{|c|}{ Spline GARCH model 2} \\
\hline$\mu$ & -0.001 & -0.002 & -0.002 & -0.001 & -0.001 \\
\hline$\rho$ & $0.123^{* * *}$ & $0.223^{* * *}$ & $0.251^{* * *}$ & $0.204^{* * *}$ & $0.070^{* *}$ \\
\hline$\alpha$ & $0.174^{* * *}$ & $0.191^{* * *}$ & $0.214^{* * *}$ & $0.104^{* * *}$ & $0.150 * * *$ \\
\hline$\beta$ & 0.129 * & 0.171 ** & $0.439 * * *$ & $0.731^{* * *}$ & $0.358^{* * *}$ \\
\hline Log-likelihood & 3677.2 & 2766.7 & 2783.3 & 3762.2 & 3775.3 \\
\hline Aikaike & -4.359 & -4.585 & -4.612 & -4.460 & -4.476 \\
\hline $\mathrm{BIC}$ & -4.294 & -4.517 & -4.544 & -4.396 & -4.411 \\
\hline
\end{tabular}

Source: Author's calculations.

1/ Estimations for the 1875-2009 period utilize the maximum number of observations available. Significance of the coefficients at the 1,5 , and 10 percent levels is denoted by ${ }^{* * *},{ }^{* *}$, and ${ }^{*}$ respectively. 
Table 4. Food Commodity Low Frequency Volatility Correlations, 1875-2009 1/

\begin{tabular}{|c|c|c|c|c|c|c|}
\hline & \multicolumn{6}{|c|}{ January 1875 - September 2009 2/ } \\
\hline & Corn & Palm oil & Rice & Soybeans & Sugar & Wheat \\
\hline Corn & 1.00 & & & & & \\
\hline Palm oil & 0.62 & 1.00 & & & & \\
\hline Rice & 0.03 & -0.22 & 1.00 & & & \\
\hline Soybeans & 0.61 & 0.94 & -0.01 & 1.00 & & \\
\hline Sugar & -0.47 & -0.01 & 0.90 & -0.48 & 1.00 & \\
\hline Wheat & 0.23 & 0.35 & -0.34 & 0.31 & -0.45 & 1.00 \\
\hline \multirow[t]{3}{*}{ Average } & 0.21 & 0.34 & 0.07 & 0.27 & -0.10 & 0.02 \\
\hline & \multicolumn{6}{|c|}{ January 1957 - September 2009} \\
\hline & Corn & Palm oil & Rice & Soybeans & Sugar & Wheat \\
\hline Corn & 1.00 & & & & & \\
\hline Palm oil & 0.79 & 1.00 & & & & \\
\hline Rice & 0.19 & 0.25 & 1.00 & & & \\
\hline Soybeans & 0.68 & 0.32 & -0.17 & 1.00 & & \\
\hline Sugar & 0.03 & 0.23 & -0.34 & 0.11 & 1.00 & \\
\hline Wheat & 0.82 & 0.44 & 0.06 & 0.76 & -0.23 & 1.00 \\
\hline Average & 0.50 & 0.41 & 0.00 & 0.34 & -0.04 & 0.37 \\
\hline
\end{tabular}

Source: International Monetary Fund

$1 /$ Calculated using monthly log changes and based on models with 5 year knot points.

2/ Correlations for the 1875-2009 period utilize the maximum number of observations available. 
Figure 2. Low-Frequency Volatility Estimates, 1875-2009

(annualized percent standard deviation)
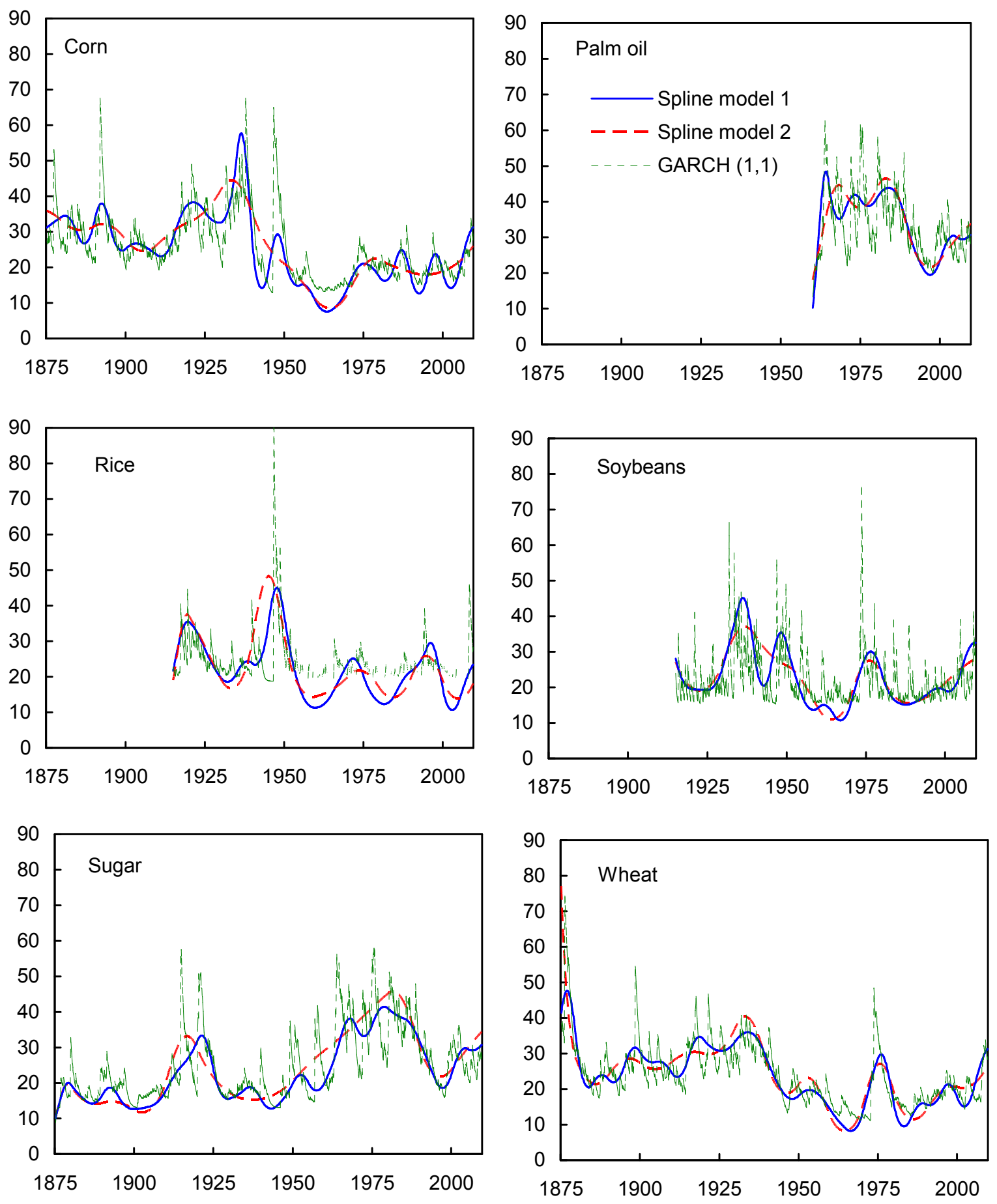

Source: Author's calculations. 
Figure 3. Low-Frequency Volatility Estimates, 1960-2009 1/ (annualized percent standard deviation)
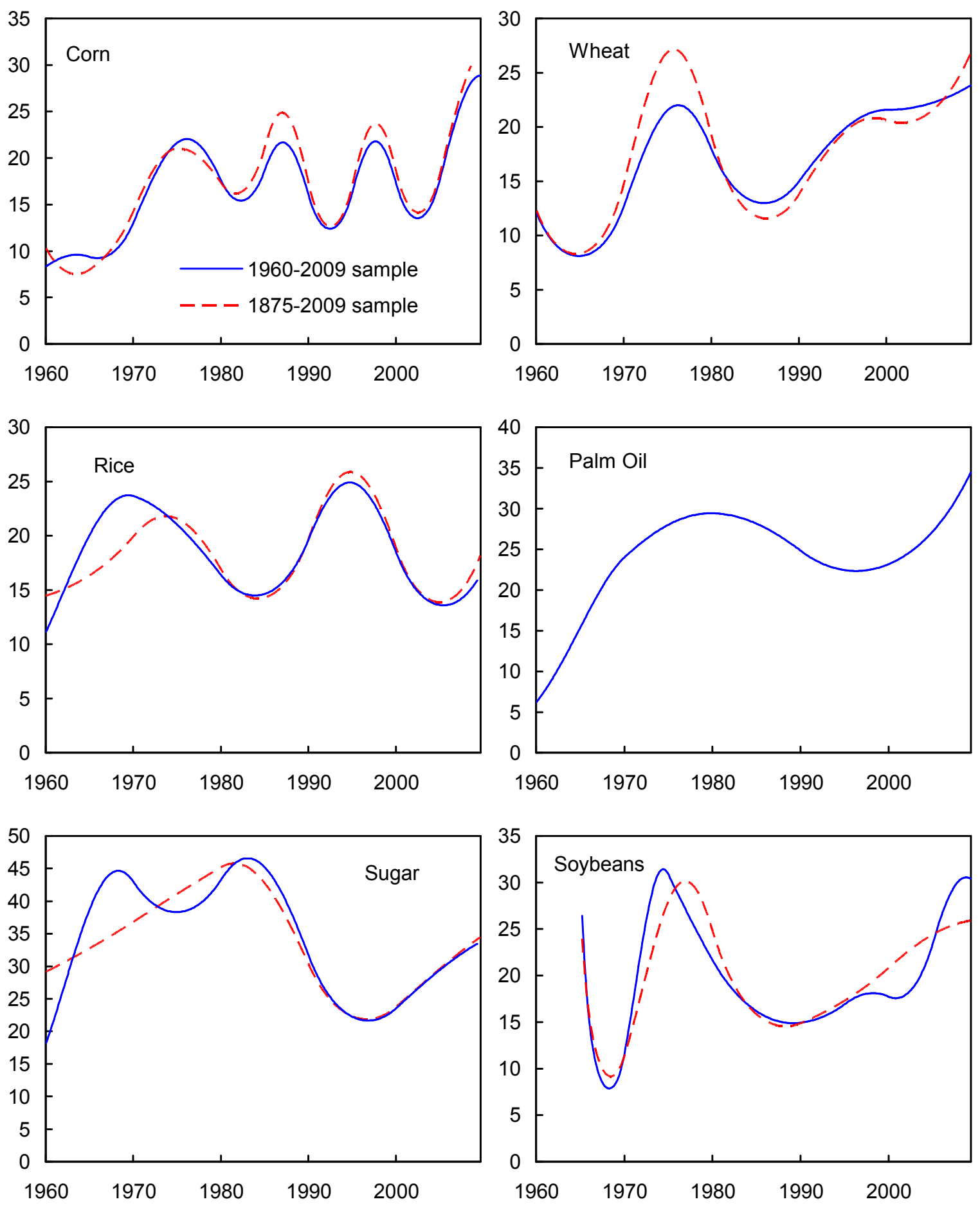

Source: Author's calculations.

$1 /$ Using the optimal spline specification identified by SBC information criteria. 
The Determinants of Low-Frequency Food Price Volatility

The second part of the analysis identifies factors that affect the level of low frequency volatility. Out of the 16 variables considered as possible determinants of volatility, seven emerged as having had a statistically significant and relatively consistent impact over the 1968-2009 period (the start date is determined by the availability of data for all regressors). Table 5 presents the results from the most parsimonious specifications based on (6) and (7).

Table 5. Determinants of Low Frequency Volatility: Regression Estimates 1968-2009

\begin{tabular}{|c|c|c|c|c|c|c|c|c|}
\hline & \multirow{3}{*}{\multicolumn{2}{|c|}{$\begin{array}{l}\text { Bivariate } \\
\text { regressions commodities }\end{array}$}} & \multicolumn{6}{|c|}{ System regression 1/ 2/ } \\
\hline & & & \multicolumn{5}{|c|}{ Without } & \multirow{2}{*}{$\begin{array}{l}\text { Corn, wheat \& } \\
\text { soybeans }\end{array}$} \\
\hline & & & corn & wheat & palm oil & sugar & soybeans $\mathrm{s}$ & \\
\hline \multicolumn{9}{|l|}{ Coefficients $3 /$} \\
\hline Stock-use ratio & -0.09 & $\ldots$ & $\ldots$ & $\ldots$ & $\cdots$ & $\ldots$ & $\ldots$ & $\cdots$ \\
\hline Inflation rate & $0.57^{* * *}$ & $\ldots$ & $\ldots$ & $\ldots$ & $\ldots$ & $\ldots$ & $\ldots$ & $\ldots$ \\
\hline Real interest rate & $-0.65 * *$ & $-0.46 * *$ & $-0.54 * *$ & -0.16 & -0.53 * & -0.94 * & *** -0.15 & $-1.22 * * *$ \\
\hline Yield curve & -0.32 & $\ldots$ & & $\ldots$ & $\ldots$ & $\ldots$ & $\ldots$ & $\ldots$ \\
\hline Real activity index & $0.04 * *$ & $-0.05 * *$ & $-0.05^{* *}$ & $-0.05 * *$ & $-0.05 * *$ & $-0.05 *$ & $-0.05 * *$ & $-0.05 *$ \\
\hline Inflation volatility & $4.47^{* * *}$ & $\ldots$ & $\ldots$ & $\ldots$ & $\ldots$ & $\ldots$ & $\ldots$ & $\ldots$ \\
\hline Interest rate volatility & $0.02 * *$ & 0.00 & 0.00 & 0.00 & 0.00 & 0.00 & 0.00 & 0.00 \\
\hline Yield curve volatility & 0.01 ** & $\ldots$ & $\ldots$ & $\ldots$ & $\ldots$ & $\ldots$ & $\ldots$ & $\ldots$ \\
\hline Real activity index volatility & $0.04 * *$ & 0.02 ** & $0.02^{* * *}$ & $0.03^{* *}$ & $0.03 * * *$ & 0.01 & $0.03 * * *$ & 0.01 \\
\hline Exchange rate volatility & $0.49 * *$ & $0.62 * * *$ & $0.55^{* * *}$ & $0.65^{* * *}$ & $0.61^{* * *}$ & 0.85 * & $0.44^{* * *}$ & 0.91 ** \\
\hline Oil price volatility & 0.01 & $\ldots$ & $\ldots$ & $\ldots$ & $\ldots$ & $\ldots$ & $\ldots$ & $\ldots$ \\
\hline Stock market volatility & 0.08 & $-0.15 * *$ & $-0.18^{* * *}$ & -0.16 ** & $-0.18^{* * *}$ & $-0.13 *$ & $-0.11 *$ & $-0.16 * *$ \\
\hline Open interest & 0.00 & $\ldots$ & $\ldots$ & $\ldots$ & $\ldots$ & $\ldots$ & $\ldots$ & $\ldots$ \\
\hline Volumes traded & 0.02 & $0.03 * * *$ & 0.03 * & 0.02 ** & 0.03 ** & 0.02 * & 0.04 ** & 0.01 \\
\hline Southern Oscillation Index & 0.75 * & $0.46^{* *}$ & 0.34 & 0.46 & $0.54^{* *}$ & 0.62 * & 0.34 & $0.79 * * *$ \\
\hline EI Nino SST & $-0.01 *$ & $\ldots$ & $\cdots$ & $\ldots$ & $\ldots$ & $\ldots$ & $\ldots$ & $\ldots$ \\
\hline \multicolumn{9}{|c|}{ Individual inflation rate coefficients } \\
\hline Corn & & 0.03 & $\ldots$ & 0.08 & 0.01 & -0.07 & 0.15 & -0.15 \\
\hline Wheat & & 0.28 & 0.24 & $\ldots$ & 0.27 & 0.17 & 0.40 & 0.08 \\
\hline Palm oil & & $0.45 *$ & 0.40 & $0.51 *$ & $\ldots$ & 0.35 & $0.57 * *$ & $\ldots$ \\
\hline Sugar & & $1.72 * * *$ & $1.68 * * *$ & $1.78^{* * *}$ & $1.71 * * *$ & $\ldots$ & $1.85^{* * *}$ & $\ldots$ \\
\hline Soybeans & & $0.63 * *$ & $0.58 * *$ & $0.69 * *$ & $0.61 * *$ & 0.53 * & $\ldots$ & $0.45^{* * *}$ \\
\hline \multicolumn{9}{|c|}{ Individual inflation rate volatility coefficients } \\
\hline Corn & & 5.66 ** & $\ldots$ & $5.65^{* *}$ & $5.76 * *$ & 5.95 * & $5.57^{* *}$ & $6.08 * * *$ \\
\hline Wheat & & 1.71 & 1.55 & $\ldots$ & 1.77 & 1.94 & 1.74 & 1.99 \\
\hline Palm oil & & $5.35 * * *$ & $5.18^{* * *}$ & $5.37^{* * *}$ & $\ldots$ & 5.76 * & $5.09 * * *$ & $\ldots$ \\
\hline Sugar & & 4.75 & 4.56 & 4.62 & 4.76 & $\ldots$ & 4.57 & $\ldots$ \\
\hline Soybeans & & $7.95 * * *$ & $7.78^{* * *}$ & $7.93^{* * *}$ & $8.05 * * *$ & 8.20 * & $\ldots$ & $8.29 * * *$ \\
\hline \multicolumn{9}{|c|}{ Log-likelihood ratio test statistic } \\
\hline$p$-value & & 0.00 & 0.37 & 0.27 & 0.22 & 0.07 & 0.65 & 0.83 \\
\hline
\end{tabular}

Source: Author's calculations

1/ Estimated using GMM with the restrictions that: the coefficients on all explanatory variables are the same, with the exception of inflation and inflation volatility; the coefficients on the stock-use ratio, the yield curve, yield curve volatility, oil price volatility, and futures market open interest are zero.

2/ Significance at the 1, 5, and 10 percent levels are denoted by * **, and ${ }^{* * *}$ respectively, using Newey-West HAC standard errors. 


\section{Real interest rates}

Real interest rate levels are negatively related to food price volatility, but real interest rate volatility has no effect. Frankel's transmission channels apply from interest rates to commodity price changes and the link with price volatility is less clear. One possible explanation is that by reducing carry costs, lower interest rates might increase the incentive for less informed financial investors to take positions in commodity markets; indeed, there are significantly inverse correlations between the level of real interest rates and changes in volumes traded for corn and soybeans, with less robust relationships for palm oil and wheat (details on request). However, this would be more likely to have only a short-term effect on volatility as informed market participants quickly arbitrage mispricing. Quantifying the effect, a one standard deviation decline in real U.S. interest rates (which is equivalent to about $1 \frac{1 / 4}{4}$ percentage point) serves to raise low frequency price volatility by about $1 / 2$ percentage point, with the effects particularly strong for soybeans and wheat.

\section{Inflation, exchange rate, and stock market volatility effects}

Higher inflation volatility tends to increase low frequency food price variation. The sensitivities vary quite widely across commodities, but in most cases the relationship is highly significant. For example, a one standard deviation increase in annualized inflation volatility (about 40 basis points since 1968) would increase long-run real food price volatility by between 1 and 4 percentage points, depending upon the commodity. Higher levels of U.S. inflation, however, do not have a consistent impact with just sugar and, to some extent soybeans, being significantly and positively affected.

Increased U.S. dollar exchange rate volatility has a significantly positive effect on food price variation. The effect is robust to changes in specification and the set of dependent commodity variables, although it is particularly strong for corn, soybeans, and wheat. A one standard deviation increase in the volatility of the U.S. dollar's nominal effective exchange rate (about 2 percentage points since 1968) serves to increase low frequency food price variation by between 1 and 2 percentage points.

One result which is difficult to interpret is the negative and statistically significant coefficient on stock market volatility. In most cases, bivariate correlations between the two variables are modestly positive, but this inverse relationship is robust to every change in the multivariate specifications. After controlling for broader financial conditions, including real interest rates and currency developments, it appears that periods of relatively high stock market volatility are associated with tranquility in low frequency food price volatility, but there are no obvious theoretical reasons to expect a causal relationship.

\section{Futures market activity}

Higher futures market volumes increase low frequency volatility. The effect is statistically significant, but economically small; for example, the average 68 percent increase in volumes over 2008 would lead to an increase in long-run volatility of less than $1 \frac{1}{2}$ percentage points. 
However, as the discussion above suggests, some of the derivative market effects may be explained by real interest rate levels. Specifications that eased the restrictions of a common coefficient on interest rates also produced estimates for the effect of volumes that lost their statistical significance, a result which likely emerges from the generally inverse relationship between interest rates and volume changes. One caveat to these results is that futures market activity is potentially endogenous to volatility (e.g., Lamoureux and Lastrapes, 1994). As noted above, it was not possible to reject the null hypothesis that volumes traded was exogenous for any of the commodities, but this issue has yet to be resolved for futures markets more generally in the literature.

\section{Real activity levels and volatility effects}

Food price volatility increases when real global activity levels fall (e.g., during a recession) and when the variation in activity increases. These findings were largely robust to changes in both specifications and the set of dependent commodity variables. These results may have been driven by three specific periods, when activity levels as measured by freight volumes plummeted, volatility increased, and food prices exhibited large price swings, namely the early 1970s, the early to mid 1980s, and 2008-09. This suggests that recessionary periods, rather than booms, tend to drive volatility higher, and that this volatility persists. Although statistically significant, the size of the impact from changes in the real activity variables is small. A two standard deviation fall (increase) in real activity levels (volatility) would increase low-frequency food price volatility by less than 1 percentage point.

\section{El Niño/La Niña effects - also statistically significant, but small}

The El Niño - Southern Oscillation (ENSO) weather pattern cycle has a statistically significant effect on long-run volatility, although its economic significance is quite small. In particular, a 2 degrees Celsius decline in the sea surface temperature (SST) anomalies in the Niño 3.4 region - which has characterized La Niña episodes in recent decades - would lead to a an increase in low-frequency food price variation of about 0.2 percentage points. Similarly, a 2 standard deviation increase in the Southern Oscillation Index would raise food price volatility by about the same magnitude.

These effects are broadly consistent with other research in this area. For example, the USDA have found that El Niño episodes tend to increase corn and wheat yields in the United States, while La Niña episodes suppress yields and similar results have been obtained for the Southern Hemisphere (Hurtado and Berri, 1998). In general, El Niño is associated with an increased likelihood of drought in tropical land areas (affecting crops such as sugar and palm oil), whereas La Niña is associated with an increased risk of drought throughout much of the mid-latitudes, where many of the most important grains are produced, including corn, soybeans, and wheat (as noted by Columbia University's International Research Institute for Climate and Society). Given the zero-bound on inventories, this suggests that negative supply shocks in major crop producing areas should have larger effects on prices than positive shocks. Overall, however, the effects are small. This may reflect the ability of meteorologists, 
at least with current technology, to predict the occurrence of ENSO cycles several months in advance, allowing producers and consumers to adapt their plans.

\section{What does not affect low-frequency food price volatility}

Inventory-use ratios have no significant effects in any of the jointly estimated regressions. For some individual commodities, the relationship does appear to be stronger, with wheat the clearest example, but there is insufficient evidence to claim that inventories have a persistent effect on price variability. One reason might be that market participants take a longer view of supply-demand conditions than the current harvest year; in other words, supply-demand imbalances in the current year are anticipated to be corrected over the medium-term. However, food commodity stock-use ratios tend to follow relatively low frequency cycles, and imbalances can persist for a number of years, which argues that they should have some influence on unconditional volatility.

Oil price volatility also has no significant impact. Like inventories, for some commodities there exist modest bivariate correlations, with the correlation coefficient for corn and wheat at about 0.2 . Although oil prices are important for food commodity input costs, the biofuel linkage, in which some crops are used as alternative energy sources, has developed only recently and it may be too early to identify a meaningful relationship.

Policy variables, based on the OECD measures of producer support, serve to reduce price volatility in some cases, but the results are not robust and vary by commodity (Table 6). These conclusions are based on the bivariate specification (6) and a shorter 1986-2010 sample period due to data availability. The coefficient on the NPC variable is insignificant for the panel and significant only for wheat. The coefficient on the SCT variable is statistically significant (and negative) for the panel, but this result is largely due to wheat; excluding this commodity, there is no impact on low frequency price volatility. In fact, the only other commodity (along with wheat) that exhibited significant bivariate correlations with the policy variables was soybeans.

Table 6. Determinants of Low Frequency Volatility: Policy variables 1/

\begin{tabular}{lccc}
\hline & All commodities & Excluding wheat & Wheat \\
\hline Nominal Producer coefficient (NPC) & 0.85 & 1.85 & $-11.21^{* * *}$ \\
& $(1.14)$ & $(1.22)$ & $(1.59)$ \\
Single Commodity Transfer (SCT) & & & 0.00 \\
& $-0.09 * *$ & $(2.40)$ & $-0.21^{* * *}$ \\
\hline
\end{tabular}

Source: Author's calculations

1 / Significance at the 1,5 , and 10 percent levels are denoted by ${ }^{*},{ }^{* *}$, and ${ }^{* * *}$ respectively, using Newey-West HAC standard errors. 
What has explained the recent rise in food price volatility?

To answer this question, the coefficient estimates from the model estimated jointly for all food commodities (excluding rice) and with equality restrictions on the coefficients (except inflation variables) were used (second column of Table 5). These coefficients were multiplied by the relevant explanatory variables, where they were statistically significant. For each year, the product of the coefficient and the explanatory variable will provide the contribution in percentage points to the level of low frequency volatility. The example for corn is shown in Figure 4.

Figure 4. Corn: Contribution to Low-Frequency Price Volatility 1995-2009 (percent)

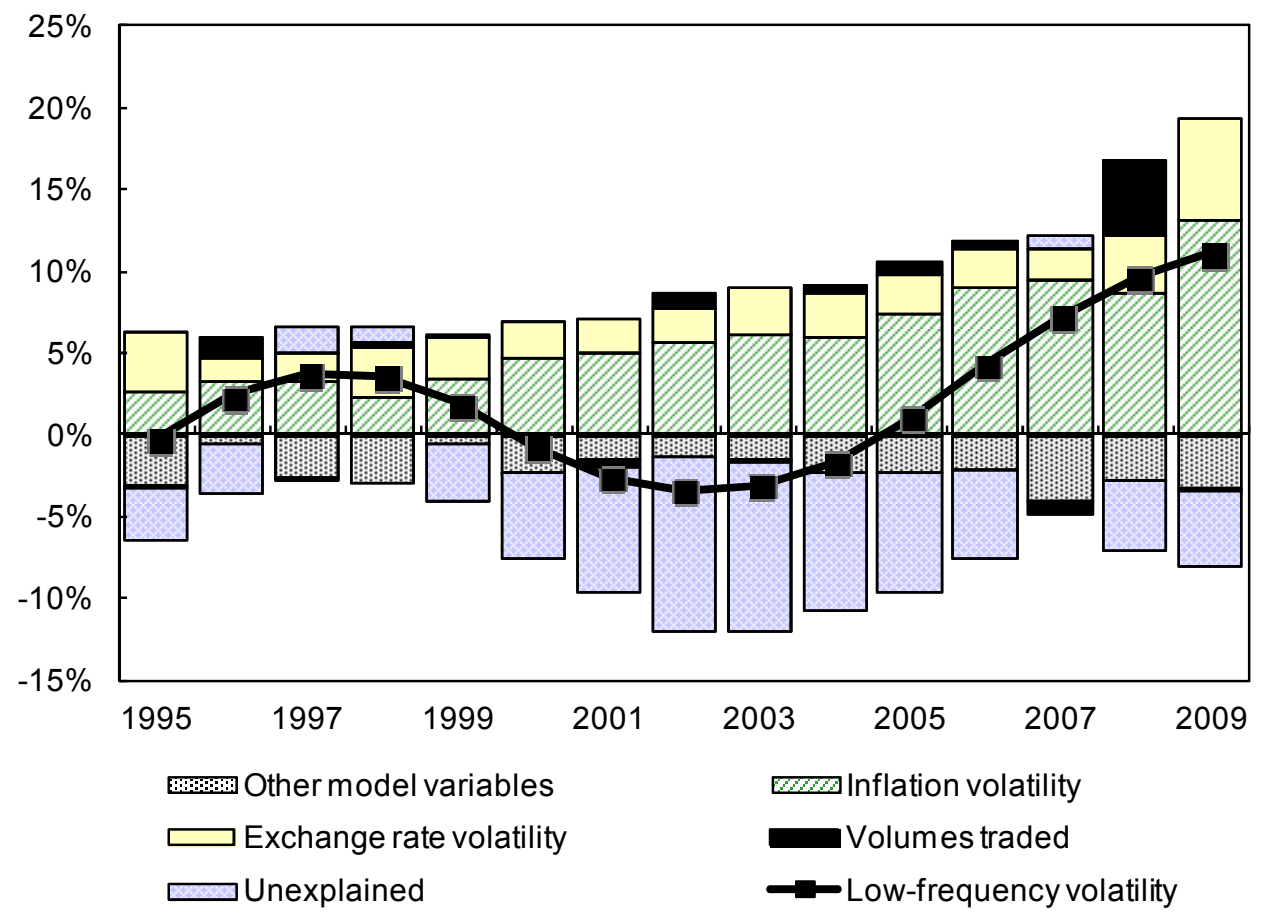

Source: Author's estimates.

One common result is that rising U.S. inflation volatility has played a large role in lifting commodity price variance. Between 1995 and 2009, inflation volatility increased from about 0.5 percent to about 2.3 percent. Combined with the large estimated coefficients for corn, palm oil, and soybeans, this has contributed almost 10 percentage points to the increase in low frequency price volatility during this period for these commodities.

Rising U.S. dollar volatility has also led to increasing commodity price variation, for all commodities included in this analysis. Dollar volatility has trended higher in recent years, rising from about 3-5 percent in the mid-1990s to reach almost 10 percent in 2009. Based on the estimated model, this has contributed to an additional 2-3 percentage points to food commodity price volatility.

Futures market volumes appear to have had a marginal effect, due mostly to the small size of the estimated coefficient from the model (a result which is subject to the caveat related to the 
possible endogeneity of volumes). The largest change in volume in recent years was for corn, which experienced an increase of about 150 percent in 2008 (marketing year). Based on the estimated coefficient, this contributed about 5 percentage points to volatility in 2008, but sustained increases would be required to have a lasting influence on volatility. For other commodities, the contribution of rising volumes was smaller with the effects also found mainly for the 2007-08 period. In other words, volumes appeared to play no major role in the broad rise in low frequency volatility which has occurred over the last 10 years.

\section{CONCLUSION}

To answer the question "what explains the rise in food price volatility?" this paper argues that it is useful to consider volatility as being made up of high and low frequency components. It may be particularly important for market participants and policymakers to gain a better understanding of low frequency volatility because it may be subject to a greater level of uncertainty with respect to its persistence and its causes. The paper presents three main findings from an analysis of low frequency volatility.

First, the slow-moving component of spot price volatility is positively correlated across different food commodities, suggesting that common factors are responsible for some portion of price variability. During the last 10 years, this measure of volatility has risen for a range of different commodities.

Second, the paper identifies a number of determinants of low frequency volatility, including: real U.S. interest rates, real global economic activity levels and volatility, U.S. inflation, the U.S. dollar exchange rate, global stock market volatility, futures market volumes, and the La Niña weather cycle. The variables with the largest effects and which also explain a relatively large part of the rise in volatility since the mid-1990s were U.S. inflation volatility and the variability of the U.S. dollar exchange rate. This lends further credence to the view that commodities are sensitive to these nominal variables, in part due to their role as real assets that hedge against both inflation and U.S. dollar depreciations.

The paper also points to aspects of food price volatility in need of further research. In particular, it finds a statistically significant positive relationship between trading volumes in commodity futures and low frequency food price volatility, adding to similar evidence found in some other studies on general food price volatility. However, it remains difficult to control for endogeneity in futures trading volumes, which likely depend to some extent on expectations of future volatility, and other studies which have failed to establish a robust relationship between futures volumes and price volatility. 


\section{REFERENCES}

Amanor-Boadu, Vincent, and Yacob A. Zereyesus, 2009, "How Much Did Speculation Contribute to Recent Food Price Inflation?" Selected Paper prepared for presentation at the Southern Agricultural Economics Association Annual Meeting.

Askari, Hossein, and John T. Cummings, 1977, "Estimating Agricultural Supply Response with the Nerlove Model: A Survey," International Economic Review, Vol. 18, No. 2, pp. 257-292.

Attié, Alexander P., and Shaun K. Roache, 2009, "Inflation Hedging for Long-Term Investors," IMF Working Paper, No. 09/90.

Bessembinder, Hendrik, and Paul J. Seguin, 1993, "Price Volatility, Trading Volume, and Market Depth: Evidence from Futures Markets," Journal of Financial and Quantitative Analysis, Vol. 28, No. 1, pp. 21-39.

Bond, Marian E., 1987, "An Econometric Study of Primary Commodity Exports from Developing Country Regions to the World," IMF Staff Papers, Vol. 34, No. 2, pp. 191-227.

Brorsen, B. Wade, 1989, "Liquidity Costs and Scalping Returns in the Corn Futures Market," Journal of Futures Markets, Vol. 9, No. 3, pp. 225-236.

Brunner, Allan D., 2002, "El Nino and World Primary Commodity Prices: Warm Water or Hot Air?," Review of Economics and Statistics, Vol. 84, No. 1, pp. 176-183.

Cashin, Paul, Hong Liang and John C. McDermott, 2000, "How Persistent Are Shocks to World Commodity Prices?” IMF Staff Papers, Vol. 47, pp. 177-217.

Cashin, Paul, and John C. McCDermott, 2002, “The Long-Run Behavior of Commodity Prices: Small Trends and Big Variability,” IMF Staff Papers, vol. 49(2), pp. 175-99.

Crain, Susan J., and Jae Ha Lee, 1996, "Volatility in Wheat Spot and Futures Markets, 19501993: Government Farm Programs, Seasonality, and Causality," Journal of Finance, Vol. 51, No.1, pp. 325-343.

Deaton, Angus, and Guy Laroque, 1992, "On the Behaviour of Commodity Prices," Review of Economic Studies, Vol. 59, No. 1, pp. 1-23.

Frankel, Jeffrey, 2006, "The Effect of Monetary Policy on Real Commodity Prices," in Asset Prices and Monetary Policy, John Campbell, ed., University of Chicago Press. 
Gilbert, Christopher L., 1989, “The Impact of Exchange Rates and Developing Country Debt on Commodity Prices,” Economic Journal, Vol. 99 (September), pp. 773-84.

,2006, "Trends and Volatility in Agricultural Commodity Prices," in Agricultural Commodity Markets and Trade, ed. Alexander Sarris and David Hallam, FAO. ,2008, "Commodity Speculation and Commodity Investment," University of Trento Department of Economics Working Paper 0820.

Hurtado, R. and Berri, G.J., 1998, "Relationship between wheat yields in the humid Pampa of Argentina and ENSO during the period 1970-1997," Tenth Brazilian Congress of Meteorology, Brasilia, Brazil.

IMF, 2008, "Is Inflation Back? Commodity Prices and Inflation," Chapter 3 in World Economic Outlook, Washington D.C.

Irwin, Scott H., and Bryce Holt, 2004, "The Effect of Large Hedge Fund and CTA Trading on Futures Market Volatility," in Commodity Trading Advisors: Risk, Performance Analysis, and Selection, Greg N. Gregoriou, Vassilios N. Karavas, Francois-Serge L'Habitant, Fabrice Rouah, eds., John Wiley and Sons, Inc.

Jacks, David S., Kevin H. O'Rourke, and Jeffrey G. Williamson, 2009, “Commodity Price Volatility and World Market Integration since 1700," NBER Working Paper 14748.

Leibtag, E., 2008, “Corn Prices Near Record High, But What About Food Costs?” Amber Waves, United States Department of Agriculture, February, pp. 11-15.

Kenyon, David, Kenneth Kling, Jim Jordan, William Seale, and Nancy McCabe, 1987, "Factors Affecting Agricultural Futures Price Variance," Journal of Futures Markets, Vol. 7. No.1 pp. 73-91.

Kilian, Lutz, 2009, "Not All Oil Price Shocks Are Alike: Disentangling Demand and Supply Shocks in the Crude Oil Market," American Economic Review, 99:3, pp. 1053-1069.

Klaassen, Franc, 2002, "Improving GARCH volatility forecasts with regime-switching GARCH,” Empirical Economics, Vol. 27, Issue 2, pp. 363-394.

Lamoureux, Christopher G., and William D. Lastrapes, "Endogenous Trading Volume and Momentum in Stock-Return Volatility," Journal of Business \& Economic Statistics, Vol. 12, No. 2, pp. 253-260. 
Mussa, Michael, 1986, "Nominal Exchange Rate Regimes and the Behavior of Real Exchange Rates: Evidence and Implications," Carnegie-Rochester Conference Series on Public Policy, Vol. 25, pp. 117-214.

Peck, Anne E., 1981, "Measures and Price Effects of Changes in Speculation on the Wheat, Corn, and Soybeans Futures Markets", in Research on Speculation, Chicago Board of Trade, Chicago.

Peterson, Hikaru Hanawa, and William G. Tomek, 2005, "How much of commodity price behavior can a rational expectations storage model explain?” Agricultural Economics, Vol. 33, pp. 289-303.

Pindyck, Robert S., 2001, “The Dynamics of Commodity Spot and Futures Markets: A Primer," The Energy Journal, vol. 22(3), pp. 1-30.

Rice, John and Murray Rosenblatt, 1983, "Smoothing Splines: Regression, Derivatives and Deconvolution," Annals of Statistics, Vol. 11, No. 1, pp. 141-156.

Roache, Shaun K., 2008, "Commodities and the Market Price of Risk," IMF Working Paper, No. 08/221.

Robles ,Miguel, Maximo Torero, and Joachim von Braun, 2009, "When Speculation Matters,” International Food Policy Research Institute Brief, no. 57.

Seale, Jr., James, Anita Regmi, and Jason Bernstein, 2003, "International Evidence on Food Consumption Patterns," United States Department of Agriculture Technical Bulletin, No. 1904.

Streeter, Deborah H., and William G. Tomek, 1992, "Variability in soybean futures prices: An integrated framework," Journal of Futures Markets, Vol. 12, No. 6, pp. 705-728.

Swaray, Raymond, 2007, "How did the demise of international commodity agreements affect volatility of primary commodity prices?" Applied Economics, Volume 39, No.17, pp. 22532260 .

Thompson, Wyatt, Seth Meyer, and Pat Westhoff, 2009, "How Does Petroleum Price and Corn Yield Volatility Affect Ethanol Markets with and without an Ethanol Use Mandate?" Energy Policy, Vol. 37, pp. 745-749.

Tomek, William G., 1998, "Structural Econometric Models: Past and Future (with Special Reference to Agricultural Economics Applications)," Proceedings of 
the NCR-134 Conference on Applied Commodity Price Analysis, Forecasting, and Market Risk Management.

Weaver, Robert D., and Natcher, William C, 2000, "Commodity Price Volatility under New Market Orientations," MPRA Paper 9862, University Library of Munich, Germany.

Williams, Jeffrey C., and Brian Wright, 1991, Storage and Commodity Markets, Cambridge University Press.

Yang, Jian, Michael S. Haigh, and David J. Leatham, 2001, “Agricultural liberalization policy and commodity price volatility: a GARCH application," Applied Economics Letters, Number 8, pp. 593-598. 


\section{APPENDIX}

Table A1. Commodity Prices Jan-1957 through August-2009: Definitions and Sources

\begin{tabular}{|c|c|c|c|c|}
\hline Commodity & Description & Source & $\begin{array}{l}\text { IMF food index } \\
\text { weight (percent) }\end{array}$ & Units \\
\hline \multicolumn{5}{|l|}{ Cereals } \\
\hline \multirow[t]{2}{*}{ Corn/ Maize } & $\begin{array}{l}\text { January } 1875 \text { through December 1956: yellow corn and yellow corn \#2 from } \\
\text { 1884-1951. Some data between September } 1943 \text { and April } 1946 \text { were } \\
\text { interpolated because no data were available. Data from } 1952 \text { on use the } \\
\text { average cash price of Corn No. } 2 \text { Yellow in Central Illinois. }\end{array}$ & $\begin{array}{l}\text { Global } \\
\text { Financial } \\
\text { Data 1/ }\end{array}$ & na & \$/bushel \\
\hline & $\begin{array}{l}\text { January } 1957 \text { through August 2009: U.S. No. } 2 \text { yellow, prompt shipment, f.o.b. } \\
\text { Gulf of Mexico ports (USDA, Livestock and Grain Market News, Washington } \\
\text { D.C.). 2/ }\end{array}$ & IMF & 6.0 & \\
\hline \multirow[t]{2}{*}{ Wheat } & $\begin{array}{l}\text { January } 1857 \text { through December 1956: No. } 1 \text { Spring Wheat; } 1871-1897, \text { No. } 2 \\
\text { Spring; } 1898-1904, \text { 'Regular' Wheat (deliverable on Contracts); } 1905-1918, \text { No. } \\
2 \text { Red Winter; 1919-1920, No. } 2 \text { Northern, } 1921-1922 \text {, No. } 2 \text { Red Northern. } \\
\text { Beginning in 1883, the basic cash price of wheat is that spot price of such } \\
\text { wheat as is being delivered on Chicago future contracts, or is expected to be } \\
\text { delivered on them, adjusted for any premium or discount applicable on delivery. }\end{array}$ & $\begin{array}{l}\text { Global } \\
\text { Financial } \\
\text { Data. }\end{array}$ & na & \$/bushel \\
\hline & $\begin{array}{l}\text { January } 1957 \text { through August 2009: U.S. No. } 1 \text { hard red winter, ordinary protein, } \\
\text { prompt shipment f.o.b Gulf of Mexico ports (USDA, Grain and Feed Market } \\
\text { News, Washington D.C.). } 2 /\end{array}$ & IMF & 10.2 & $\$ / M t$ \\
\hline \multirow[t]{2}{*}{ Rice } & $\begin{array}{l}\text { October } 1914 \text { through December 1956: All New Orleans deliveries, Fancy } \\
\text { (Honduras) from October } 1914 \text { to December 1942, Fancy (Blue Rose) from } \\
1925 \text { to 1933, for Medium to Good (Blue Rose) from January } 1934 \text { to July } \\
\text { 1947, for Fancy No. } 2 \text { Zenith Milled in New Orleans from August } 1947 \text { to } \\
\text { December } 1956 .\end{array}$ & $\begin{array}{l}\text { Global } \\
\text { Financial } \\
\text { Data. }\end{array}$ & na & $\$ / C W T$ \\
\hline & $\begin{array}{l}\text { January } 1957 \text { through August 2009: Thai, white milled, } 5 \text { percent broken } \\
\text { nominal price quotes, f.o.b. Bangkok (USDA, Rice Market News, Little Rock } \\
\text { Arkansas). 3/ }\end{array}$ & IMF & 3.6 & \$/Mt \\
\hline \multicolumn{5}{|c|}{ Vegetable oils and protein meals } \\
\hline Palm oil & $\begin{array}{l}\text { January } 1957 \text { through August 2009: Malaysian/ Indonesian, c.i.f. Northwest } \\
\text { European ports (Oil World, Hamburg). Prior to 1974, UNCTAD. 2/ }\end{array}$ & & 4.2 & $\$ / M t$ \\
\hline \multirow[t]{2}{*}{ Soybeans } & $\begin{array}{l}\text { Commodity Research Bureau Yearbook data from } 1913 \text { to } 1923 \text { was for } \\
\text { October through February only, so February's price is used for the rest of the } \\
\text { year. The average of the monthly highs and lows of CBT cash prices is used } \\
\text { through } 1949, \text { No. } 2 \text { Yellow is used from } 1950 \text { through 1953, and No. } 1 \text { Yellow } \\
\text { soybeans are used from October } 1953 \text { on. }\end{array}$ & $\begin{array}{l}\text { Global } \\
\text { Financial } \\
\text { Data. }\end{array}$ & na & \$/bushel \\
\hline & $\begin{array}{l}\text { January } 1957 \text { through August 2009: U.S. c.i.f. Rotterdam (Oil World, Hamburg). } \\
\text { 2/ }\end{array}$ & IMF & 7.2 & \$/Mt \\
\hline \multicolumn{5}{|l|}{ Sugar } \\
\hline & $\begin{array}{l}\text { January } 1875 \text { through August 2009: Wholesale prices in Philadelphia, 1784- } \\
1899 \text { using the price of Havana White Sugar. Data from } 1900 \text { on is for raw cane } \\
\text { sugar prices, } 96 \text { degree centrifugal through } 1956 .\end{array}$ & $\begin{array}{l}\text { Global } \\
\text { Financial } \\
\text { Data. }\end{array}$ & na & $\mathrm{Cts} / \mathrm{lb}$ \\
\hline Free market & $\begin{array}{l}\text { January } 1957 \text { through August 2009: International Sugar Organization price. } \\
\text { Average of the New York contract No. } 11 \text { spot price, and the London daily price } \\
\text { f.o.b. Caribbean ports (International Sugar Organization, London and the } \\
\text { Journal of Commerce, New York). Prior to 1976, New York contract No. } 11 \text { spot } \\
\text { price f.o.b. Caribbean and Brazilian ports. } 1 /\end{array}$ & IMF & 3.6 & $\mathrm{Cts} / \mathrm{lb}$ \\
\hline
\end{tabular}

Source: Global Financial Data; International Monetary Fund.

1/ Refer to www.globalfinancialdata.com for detailed descriptions and primary sources.

2/ Average of daily quotations.

$3 /$ Average of weekly quotations. 